\title{
A espectaçāo enquanto prática em Shoot the Sissy
}

Spectatorship as a practice in Shoot the Sissy

\section{Alessandra Montagner}

Alessandra Montagner Doutoranda do Programa de Pós-graduação em Artes da Cena, da Unicamp

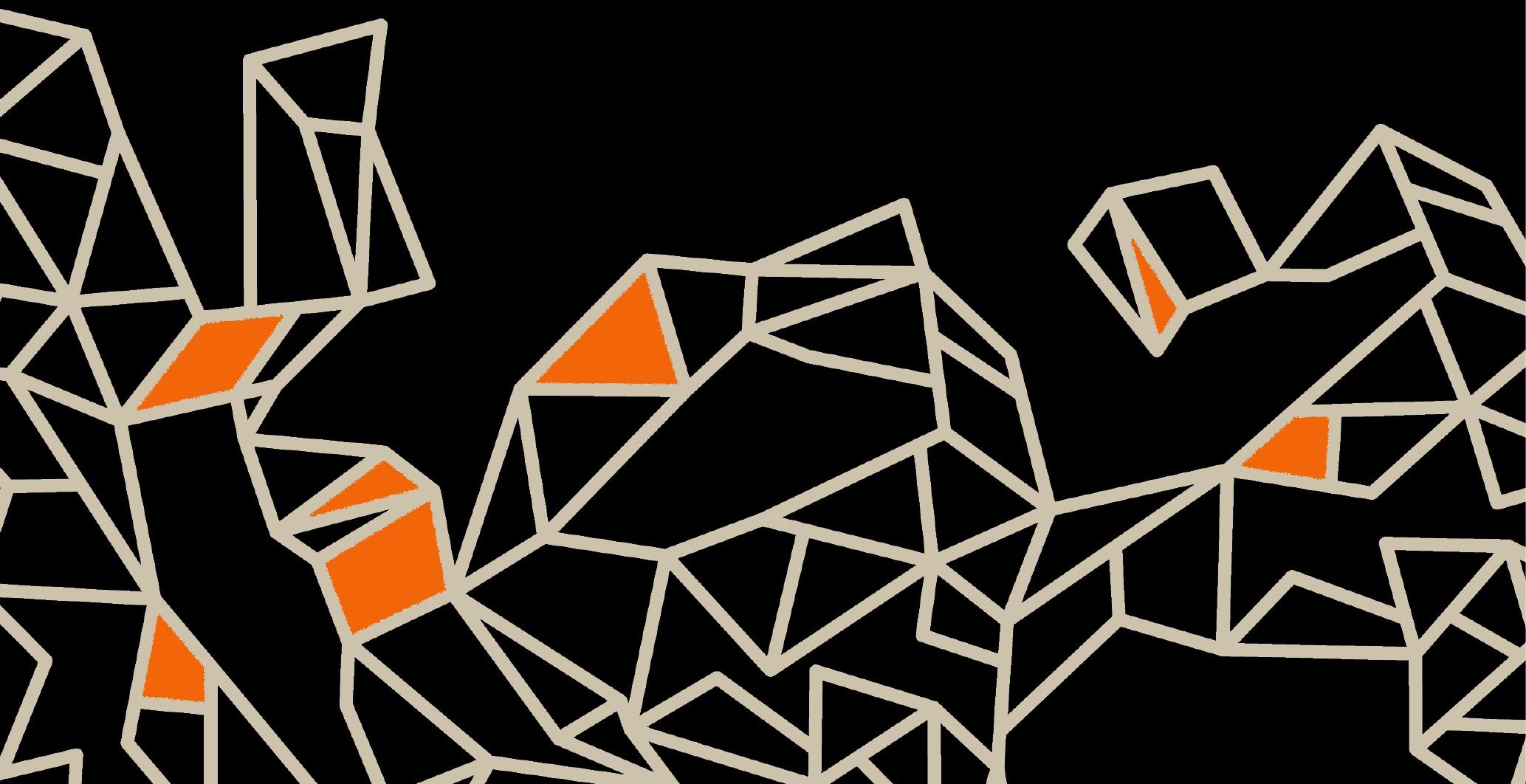




\section{Resumo}

Este artigo sugere a possibilidade de se pensar uma prática da espectação que se consolida enquanto espectação de si. Para tanto, refere-se a estrutura espectatorial proposta pela performance Shoot the Sissy, de Nando Messias, para operar um exercício reflexivo sobre tal possibilidade, utilizando-se das teorias de P.A. Skantze, Jorge Dubatti, Maurice Merleau-Ponty e Matteo Bonfitto como aporte para essa incursão.

Palavras-chave: Espectação, Prática, Shoot the Sissy.

\section{Abstract}

This paper suggests the possibility of conceiving a practice of spectating that consolidates itself as a spectatorship of the self. To that end, it refers to the spectatorial structure proposed by the performance Shoot the Sissy, by Nando Messias, to operate a reflective analysis of such possibility, using the theories of P.A. Skantze, Jorge Dubatti, Maurice Merleau-Ponty and Matteo Bonfitto as the grounds of this incursion.

Keywords: Spectatorship, Practice, Shoot the Sissy.

Este artigo busca pensar a espectação como prática por meio da relação espectatorial proposta pela performance Shoot the Sissy, de Nando Messias, performer brasileiro radicado no Reino Unido ${ }^{1}$. A obra compõe a trilogia desenvolvida por Messias sobre a figura da sissy, palavra que na língua inglesa conota as noções de efeminação e covardia e é geralmente utilizada de forma ofensiva quando dirigida a alguém; "maricas", "bicha" e "viado", entre outros, seriam os seus equivalentes no português brasileiro. $O$ projeto de explorar cenicamente a corporeidade em questão foi motivado pela experiência de Messias como vítima de agressões e assédio e, consequentemente, medo, por ruas e sociedades repletas de preconceito e ódio por habitar um corpo queer (ou kuir) - um corpo que se permite ser aquilo que é, para além de expectativas e construções de gênero binárias impostas por padrões sociais que há tanto orientam gênero e, ainda de certa forma, sexualidade. Shoot the Sissy, especificamente, consiste em uma réplica de Messias ao

1 Para saber mais sobre o performer e seu trabalho, ver <http://www.nandomessias.com/>. 
atentado de Orlando (EUA), ocorrido em junho de 2016, quando um homem abriu fogo em uma casa noturna frequentada pela comunidade gay, matando em torno de 50 pessoas e ferindo outras 53. O atentando causou grande comoção internacional pelo ódio expresso em um ato que englobou, certeiramente, o horror da homofobia que ameaça e terrifica, com atos de extrema brutalidade e intolerância, a comunidade LGBT², além de invocar a sombra que o terrorismo impõe sobre nações na atualidade - uma vez que existe a suspeita de que o massacre tenha sido motivado por convicções extremistas. Assim, Messias concebeu o conceito central de Shoot the Sissy como forma de resposta à violência sofrida pela comunidade LGBT, naquela ocasião específica, também sentida por ele nas agressões direcionadas ao seu próprio corpo no cotidiano.

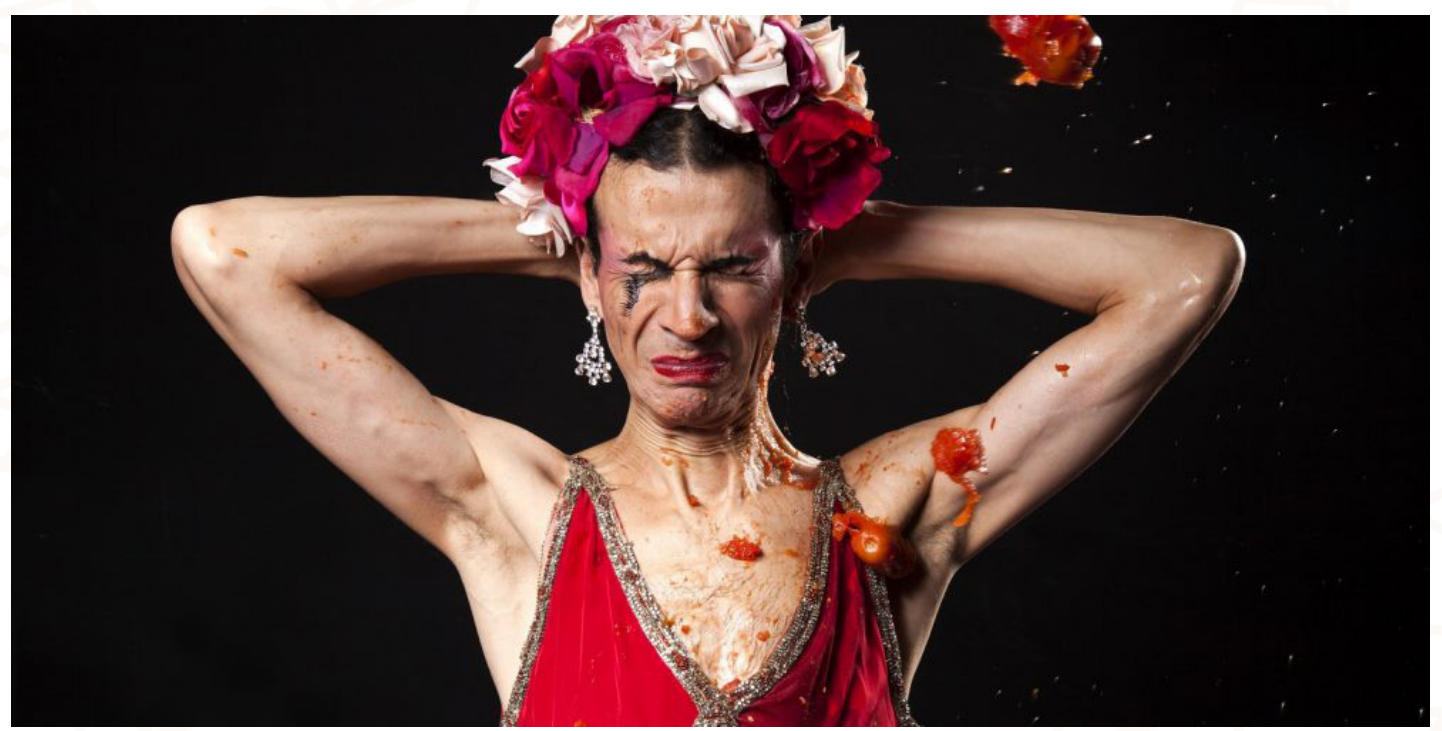

Figura 1 - Imagem utilizada na divulgação de Shoot the Sissy. Foto: Holly Revell.

Nando Messias estruturou Shoot the Sissy ao redor da ideia do freak show: espetáculo pautado na apresentação de corpos considerados aberrações - tanto para os padrões biológicos quanto sociais -, com a finalidade de apresentar à sua audiência um "circo dos horrores" e o intuito de promover tanto uma forma de entretenimento quanto uma experiência do choque. Contudo, essa performance não se instaura enquanto cena que choca de forma direta, mas se estabelece por vias de sutileza mediante o convite para

2 Acrônimo de lésbicas, gays, bissexuais, travestis, transexuais e transgêneros, também representada por LGBTTT - LGBTQ inclui queer, mas não é usual no Brasil. 
adentrar a realidade identitária, de vulnerabilidade e resistência, que compõe a figura da Sissy. A obra opera por meio de uma teatralidade comovente, certamente construída com uma qualidade teatral, e até mesmo representacional em certos momentos, mas por vias de afecção performativa: que envolve e sutilmente abala, talvez para tornar consciente uma questão que pode passar desapercebida por muitos de nós que não compartilhamos da mesma corporeidade de Messias. Sissy não é necessariamente uma personagem, desenvolvida com meandros cuidadosos e lapidada em sua gênese, mas uma entidade atuante que se encontra aprisionada em um círculo de exploração, violência, desejo e dever no contexto da performance.

O cenário da obra sugere um circo, com um pequeno picadeiro localizado no centro do palco e rodeado por feno que cobre parte do chão; e o espaço da performance se enquadra na delimitação da caixa preta e na estruturação do palco italiano. Sissy parece ser empurrada para dentro do palco (por alguém que não pode ser visto) e traz consigo, em uma mala, pertences que sugerem uma feminilidade estereotipada - bolsas, maquiagem, sapatos etc. - que aos poucos vai sendo revelada para a audiência. Na maneira glamorosa de se conduzir e vestir, no contexto da obra, Sissy apresenta-se enquanto corporeidade que invocava os modos de uma diva, de lady de uma época remota, de uma Maria Callas que ousa existir sobre a pele de um corpo masculino porque assim o deseja, e de uma sedução perdida que também ressoa na voz e canções de Edith Piaf. Ela constantemente se deixa levar pelo encantamento que sente pelo seu próprio universo e pelos pertences que definem a sua identidade, mas é constantemente interrompida por um outro (imaginário) que insiste em recordá-la, de forma intimidadora, da importância de seguir com o show. O espetáculo demandado por esse outro oculto consistia no lento fuzilamento de Sissy, oferecida enquanto comodidade disponível aos tiros simbólicos a serem cometidos pelos espectadores. Ela seleciona os membros da audiência que arremessariam objetos na sua direção (ovos recheados de papel picado, farinha, tomates, entre outros). Alguns espectadores se mostravam hesitantes em disparar, receosos de machucá-la - eu me encontrava na plateia, mas não fui escolhida para os arremessos -, porém ela os encorajava, pois, como afirmava, "a Sissy não sente dor”, potencialmente, fazendo referência à habitual violência direcionada ao corpo queer. Ao longo 
da performance, a figura gradativamente se despe da vestimenta e maquiagem impecáveis, desconstruindo sua aparência de dama para progressivamente instaurar uma outra realidade da corporeidade abordada: despida, suja, descabelada, desfigurada pela cor vermelha que the cobre toda a face - visualmente sugerindo sangue (?) -, ela revela a vulnerabilidade e o sofrimento que assolam a sua condição.

Dentre os vários momentos e elementos da performance, o que interessa ao contexto deste artigo é o momento no qual espectadores deveriam arremessar objetos diversos na direção do performer. O momento no qual eles eram convidados a praticar uma ação violenta na direção de um corpo queer e, portanto, hospedar em seus corpos um ato simbólico de ataque e agressão a Sissy. Logo, inseridos em um exercício espectatorial que se consolidava em ato - ação/prática que instaura o performativo e é determinante no contexto que se manifesta -, atirar na direção da Sissy era exercer a responsabilidade do tiro e do ataque não apenas àquele corpo, mas a todas as outras Sissies. $\mathrm{O}$ ato demandado dos espectadores carrega consigo uma ameaça, pois, talvez, nesse processo discriminatório e agressivo, direcionado ao corpo queer, sejamos nós os perpetuadores da violência que condenamos. De qualquer forma, o que essa problemática, proposta pela obra, revela sobre os modos de espectação na contemporaneidade?

\section{Sobre a cena}

O trabalho de Nando Messias engloba as poéticas de dança, teatro e arte da performance e estabelece-se enquanto cena híbrida que não evidencia fronteiras entre diferentes linguagens da cena, mas as complexifica na criação de uma obra única e "autorreferente" (BONFITTO, 2013), permeada por uma teatralidade particular e mestiçada. Logo, é importante salientar que o teatro - enquanto recorte da experiência espectatorial proposto por esse editorial - é abordado neste ensaio pelo viés de cena que não se encerra em categorizações e restrições poéticas. Uma possibilidade de considerar o teatro por tal viés expandido parece possível por meio do recorte operado por Jorge Dubatti no campo da "Filosofia do teatro", no qual esse seria, antes de tudo, um acontecimento composto pela tríade convívio, poiesis e expectação 
(DUBATTI, 2011). O aspecto convivial desse acontecimento, segundo o autor, refere-se a um procedimento ancestral da humanidade de reunir-se com outros e agregar-se ao grupo por meio de práticas de coexistência diversas. A partir desse acontecimento convivial, dois outros aspectos seriam implementados para a instauração do evento teatral: a poiesis e a expectação. Dubatti coloca que esses dois últimos aspectos de sua concepção de teatro referem-se à divisão trabalhista constituinte do acontecimento, em que a poiesis compreende as camadas produtivas e artesanais de composição e (a)presentação da obra, e a expectação refere-se ao exercício espectatorial sobre a obra produzida. $\mathrm{O}$ autor salienta nesse processo, ainda, a alteridade implícita na expectação, ou no encontrar-se e conviver em um tempo-espaço específico e (de)limitado com um outro que se apresenta e é recebido como tal - como outro. Portanto, o enquadramento do evento teatral enquanto acontecimento convivial parece fornecer a possibilidade de pensar o teatro como cena de diversas possibilidades, não delimitadas por uma poética pré-determinada já que a grande pergunta da disciplina desenvolvida por Dubatti é, precisamente, "O que é o teatro?" -, mas, ao contrário, que se foca sobre os pilares que sustentam a estrutura do evento cênico: o convívio, a cena, o ato espectatorial. Logo, nesse ensaio tanto o teatro quanto a performance em questão são abordados pela noção de cena: dentro da qual o convívio com outros, a relação com a poiesis, e a expectação proporcionam zonas (inter-) relacionais que fomentam conjunturas de encontro, interpelação e potencial alargamento perceptivo na fundação de práticas relacionadas ao ato espectatorial. Mas o que configuraria tais práticas? Aliás, é possível pensarmos o ato espectatorial como prática?

\section{A prática da espectação}

No livro Itinerant spectator/Itinerant spectacle, P. A. Skantze faz menção ao que, na língua inglesa, ela chama de the practice of spectating. Skantze refere-se especificamente às suas experiências como espectadora deambuladora, que se deslocava por cidades, locais e países no continente europeu - contexto coberto pelo livro - para ver peças que também se deslocam por diferentes polos geográficos para encontrar suas audiências - logo, 
espectadora itinerante de peças itinerantes. O que a autora estabelece como prática no ato espectatorial é uma série de rituais e procedimentos que vão desde a escolha de uma peça, a compra do ingresso, a soma de percepções das diversas culturas e etiquetas na conjuntura do evento teatral, até a relação com o espaço do teatro e, finalmente, a interação com a obra apreciada e os diversos processos subjetivos emergentes de cada uma dessas experiências. Logo, processos que a instruíram em uma prática espectatorial elaborada de forma "intuitiva, cumulativa e artesanal" e que se assemelha aos procedimentos de criação e composição da cena (SKANTZE, 2013, p. 7).

Igualmente, a gama de associações, aversões e imagens derivada do exercício espectatorial diante de diferentes linguagens da cena, em especial, contribuíam para a construção processual de um sistema referencial relativo tanto às artes da cena quanto ao ato espectatorial diante de cenas diversas: uma formação de implicações estéticas, éticas e políticas. Nessa incursão, Skantze legitima como prática momentos que podem facilmente passar desapercebidos, e que não são necessariamente endereçados dentro do contexto da relação do espectador com a cena - por exemplo, uma fila longa na compra de um ingresso, a frustação de não conseguir comprar a entrada, etc. Do argumento da autora, o mais relevante para este artigo é a possibilidade inesperada de referirmo-nos aos processos espectatoriais como práticas no contexto do vocabulário que permeia as artes da cena, pois prática, até então, é essencialmente uma palavra utilizada em referência ao labor do artista que compõe a cena. Logo, é fato curioso o atrelar do ato espectatorial à ideia de prática, afinal não seria o espectador o oposto do praticante? Sobretudo, o que praticaria o potencial praticante-espectador no contexto da obra aqui abordada?

No que tange a expressão the practice of spectating, ela pode, na língua portuguesa, ser traduzida por (i) prática da recepção ou (ii) prática da expectação - de acordo com o termo utilizado por Dubatti. Porém, sugiro uma pequena alteração na grafia do termo (já empregada acima) que emprestamos desse autor: espectação. O termo recepção é um conceito já estabilizado e reconhecido dentro dos estudos referentes à cena, pois, advindo dos estudos literários, traz consigo uma linhagem teórica que engloba uma longa tradição de análise das diferentes camadas das relações 
espectatoriais com a recepção do objeto de arte. Numa abordagem menos especializada, a palavra recepção também carrega a ideia de alguém que recebe algo: um receptor. A função geral do receptor, nos diferentes contextos que habita, é de receber, fazer passar e/ou decodificar um código ou mensagem para a efetivação do processo comunicativo. Dessa forma, parece apropriado problematizar a escolha por esse termo no contexto da cena que se estabelece por vias de afecção e participação imersivas - ao invés de comunicar uma mensagem -, pois, mesmo que o ato do espectador se estabeleça pela inter-relação entre o semiótico e o fenomênico, existe na noção de receptor uma imobilidade que, nesse contexto, parece insuficiente para apreender a condição espectatorial. Contudo, a noção de expectação trazida por Dubatti parece mais fecunda para tratar a dimensão fenomênica que compõe a experiência espectatorial proposta por Shoot the Sissy e o deslocamento ontológico que essa obra propõe ao espectador.

Existem, ainda, duas palavras designadas em duas línguas distintas para nomear $\mathrm{o}$ ato do espectador, e que possivelmente possam ajudar a iluminar o porquê da escolha feita pela palavra espectação (escolha que não se dá de forma descomplicada): spectatorship e expectación. Spectatorship, na língua inglesa, faz referência à natureza do ser espectador, cujo sufixo -ship denota uma qualidade e evidencia uma condição. Por sua vez, a palavra expectação tem sido crescentemente implementada como outra forma de referência ao processo espectatorial e parece ter surgido como tradução direta do termo espanhol expectación, empregado por Dubatti, como mencionado acima. Por sua vez, expectação em português denota expectativa: o esperar ansiosamente por algo que se almeja, a ansiedade que olha com determinação para um horizonte que se deseja ver realizado. Logo, a escolha terminológica feita por Dubatti, e traduzida para o português como expectação, é de certa forma certeira quando direcionada ao ato espectatorial, pois adiciona uma dimensão de anseio pela cena. $\mathrm{Na}$ expectação o espectador se tornaria expectador, desejante do acontecimento e sedento pela relação convivial da cena. Mas seria expectação um termo certeiro para pensarmos as dimensões da experiência espectatorial? A escolha por esse termo, para além de interessante, também parece insuficiente, pois determina dentro das articulações linguísticas da língua portuguesa um aspecto do ato espectatorial que o demarca de forma 
limitada: a palavra expectação soa demasiadamente contaminada por sua expectativa implícita, que compreende $o$ ato espectatorial, mas não o define inteiramente. Opto por subverter a grafia da palavra em questão para espectação, a fim de trazê-la para mais perto de espectador. Embora o termo espectação já seja relativamente utilizado, especialmente nos estudos de cinema no Brasil, carecemos ainda de uma melhor conceituação, reflexão sobre a validade e, talvez, necessidade desse termo no nosso vocabulário técnico. Por fim, a prática da espectação parece a melhor escolha de tradução para a expressão the practice of spectating, que empresto de P. A. Skantze, para abordar as dimensões das práticas espectatoriais fomentadas pelas relações com a cena da contemporaneidade. Porém, o que constituiria uma prática da espectação?

A prática traz consigo a ideia de um "ato ou efeito de praticar", refere-se a "uso, experiência, exercício"; denota "rotina, hábito" ou "saber provindo da experiência" ou "técnica." Praticar também abrange a "aplicação de uma teoria" (Dicionário Aurélio) ou o "colocar em prática." No contexto da espectação da cena, as práticas que compõem o ato do espectador são de naturezas variáveis: concernem à logística do seu comparecimento e presença no evento, bem como aos processos éticos, estéticos e políticos no seu encontro com a cena. Dessa forma, seria mais viável falarmos de práticas da espectação em vez de presumir que um processo único ocorra na interação espectatorial com a cena, pois não existe um espectador que possa exemplificar todos os restantes, dado o fato de experiências - como a espectação o é - serem de natureza pessoal. De qualquer modo, os diferentes tipos de teatralidade e performatividade produzidos por cenas diversas orientam os espectadores por estratégias que, por vezes, podem desestabilizar práticas previamente construídas e validadas. Isso pode se dar pela complicação da posição do espectador diante da cena testemunhada: seria ele observador, testemunha, participante ou praticante?

A espectação, assim como a percepção, instaura-se pelos sentidos: pelos olhos que veem, ouvidos que ouvem, peles envoltas ou repelidas pela atmosfera do evento, gostos imaginados ou legítimos, e, ainda, cheiros sugestivos de memórias e imagens ou fortes odores instaurados. "[...] Na percepção os sentidos se comunicam assim como na visão os dois olhos colaboram" na formação de uma imagem (MERLEAU-PONTY, 2011, p. 314). Tanto na 
apreensão da imagem ou na relação com a cena, os processos perceptivos não são binários, não excluem o intelecto em exercício separatista entre 0 corpo que é e o corpo que pensa; pelo contrário, salientam o entrelaçamento entre as diferentes camadas do ser. Na circunstância espectatorial, esse ser refere-se a um ser diante da obra, que afeta-se no contexto do acontecimento com aquilo que a cena propõe e o que pode ser percebido, ou a inabilidade de apreendê-lo. No contexto da cena contemporânea, híbrida e mestiçada de estratégias oriundas das diferentes poéticas da cena, o percebido pode ser também insuportável, insustentável na relação espectatorial com a cena e com o ser. Nesse caso, a vivência proporcionada e proposta por uma obra pode instaurar um conflito de caráter ontológico no espectador que se defronta com a obra, problematizando posturas e formas de relação estabelecidas e instigando novas formas do ser-espectador. Nessa circunstância, existe a possibilidade de instauração de uma prática de confrontação com o ser diante do outro, ou como se colocar diante do outro e da cena. A prática fomentada por tal confronto pode promover uma abertura na direção do outro, onde o acontecimento enquadra a espectação enquanto ato intersubjetivo, potencialmente fomentando um alargamento perceptivo não apenas das questões exploradas por uma obra específica, mas também equipando o espectador para uma espectação de si. Logo, a coexistência com e através do outro, em um exercício simbólico, pode possibilitar que o espectador se torne praticante de uma consciência de si, espectador das suas respostas e posições perante a cena, que podem vir a afetar o seu "existir diante" do outro na vida; pois "há dois sentidos e apenas dois sentidos da palavra existir: existe-se como coisa ou existe-se como consciência. A experiência do corpo próprio, ao contrário, revela-nos um modo de existência ambíguo" (MERLEAU-PONTY, 2011, p. 268). E nessa ambiguidade a espectação se problematiza.

\section{Atire, espectador, mas tome cuidado para não se ferir no processo}

Shoot the Sissy oferece um bom caso para se pensar a espectação enquanto prática, pois fornece material de análise e uma estrutura cênica que depende de e inclui espectadores de forma um tanto complicada, mesmo 
que sutil. Nesse sentido, os espectadores convidados a arremessarem objetos no performer, mirando muitas vezes em partes delicadas, como a face, eram igualmente incluídos em um sistema que salienta problemáticas éticas diante do ato demandado. Arremessar algo na direção de alguém exige um adensamento de motivações que justifiquem a possibilidade de um ferimento. Na performance, embora os arremessos operassem principalmente por sistemas simbólicos, era possível reconhecer nos espectadores envolvidos certo impasse diante de tal ato. Esse impasse tomou a forma tanto de excitações como de arremessos fracos que não cumpriam o que deveriam, não possibilitavam que os objetos se esfacelassem ao dar de encontro com o corpo de Messias. Logo, o ataque à figura da Sissy não parecia ser apenas direcionado a esta, mas também era instaurado num confronto entre agente e ato, dos espectadores consigo próprios. A estrutura participativa demandada da espectação da obra propunha, portanto, certo confronto pessoal ao requerer que o espectador jogasse o objeto com a força necessária para quebrá-lo no corpo alheio e, essencialmente, no corpo queer. Era um conflito que se instaurava preciosamente no campo de afecção, entre performer e espectador, objeto e sujeito; um encontro com o outro que se revertia em confronto consigo; ou, ainda, uma interpelação do espectador pela corporeidade performada que se impunha sobre ele.

[...] para que o objeto possa existir em relação ao sujeito, não basta que este "sujeito" o envolva com o olhar ou o apreenda assim como minha mão apreende este pedaço de madeira, é preciso ainda que ele saiba que o apreende ou o olha, que ele se conheça apreendendo ou olhando, que seu ato seja inteiramente dado a si mesmo e que, enfim, este sujeito seja somente aquilo que ele tem consciência de ser, sem o que nós teríamos uma apreensão do objeto ou um olhar o objeto para um terceiro testemunho, mas o pretenso sujeito, por não ter consciência de si, se dispersaria em seu ato e não teria consciência de nada. (MERLEAU-PONTY, 2011, p. 318)

Conclusivamente, na prática da espectação proposta por Shoot the Sissy, participativa e inquisidora, se fornece à sua audiência, através dos atos de arremesso, um contexto no qual existe a possibilidade do estabelecimento de um exercício reflexivo validado pela possível instauração de uma espectação 
de si. A obra era de uma beleza e delicadeza mortificantes e arrebatadoras, e o encontro com a vulnerabilidade do outro, ressaltada pela demanda de um ato violento que é meu - do espectador - denuncia limitações e impasses pessoais diante de questões levantadas e reveladas pela performance e frente ao outro que não se apreende em totalidade. E por não apreendê-lo, ele me interpela, e eu me estranho.

\section{Referências bibliográficas}

BONFITTO, M. Entre o ator e o performer: alteridades, presenças, ambivalências.

São Paulo: Perspectiva/Fapesp, 2013.

DUBATTI, J. Introducción a los estudios teatrales. México: Libros de Godot, 2011. SKANTZE, P. A. Itinerant spectator/Itinerant spectacle. New York: Punctum, 2013. MERLEAU-PONTY, M. Fenomenologia da percepção. São Paulo: WMF Martins

Fontes, 2011.

Recebido em 16/03/2017

Aprovado em 22/05/2017

Publicado em 17/07/2017 